\title{
Factors associated with the resilience of family caregivers of persons with dementia: a systematic review
}

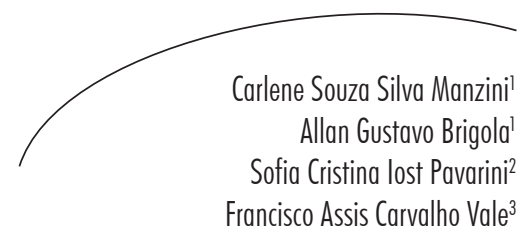

\section{Abstract}

Background: Resilience is the ability of individuals or groups to overcome adversity without displaying physical or mental disorders, or even learning to deal with unfavorable conditions more efficiently. There have been many studies on resilience, which try to identify the conditions under which people in situations of deprivation or adversity overcome such challenges. Objective: The present article aimed to identify factors associated the with development of resilience in family caregivers of people with dementia and the possible outcomes of resilience for the caregiver and receiver of care. Method: The study consisted of a systematic literature review carried out in accordance with the PRISMA methodology with searches in the Lilacs, PsycInfo, PubMed, SciELO, SCOPUS and Web of Science databases, using pre-established descriptors. Results: After synthesis of the extracted data and the considerations of this review, it was possible to identify possible factors associated with the development of resilience in family caregivers of persons with dementia: depression, anxiety, burden, drug use, the relationship with the person receiving care and health conditions are associated with the resilience of family caregivers. Conclusion: We found in literature that the development of resilience by family caregivers of people with Alzheimer's is influenced by factors related to the patient and the caregiver himself or herself.

\footnotetext{
Universidade Federal de São Carlos, Programa de Pós Graduação em Enfermagem. São Carlos, São Paulo, Brasil.

2 Universidade Federal de São Carlos, Departamento de Gerontologia, Programa de Pós Graduação em Enfermagem. São Carlos, São Paulo, Brasil.

3 Universidade Federal de São Carlos, Departamento de Medicina; Programa de Pós Graduação Enfermagem. São Carlos, São Paulo, Brasil.

Correspondence

Carlene Souza Silva Manzini.

E-mail: carlotamanzi@hotmail.com.
}

Keywords: Psychological resilience. Caregivers. Family. Dementia. Alzheimer's disease. 


\section{INTRODUCTION}

Dealing with emotions, controlling impulses, being optimistic and expressing empathy are attitudes of overcoming difficulties that have been analyzed by the scientific community in an attempt to determine why certain people are more likely to overcome a problem than others.

When these abilities are analyzed from different points of view, a wide range of conclusions can be drawn: biologists claim that humans have the genetic potential to become more resilient; psychologists claim that the family is responsible for the development of the ability to overcome problems; sociologists believe that cultural and traditional influences give humans this ability to resist; and theologians understand that trials and challenges are essential for human beings to evolve and grow stronger. ${ }^{1}$ Despite these differences, there is a general consensus that certain people can overcome problems and return to their normal lives, or indeed improve them, when faced with tragedies and problems, whereas others suffer a great deal more.

Some authors believe that resilience is a personality characteristic that moderates the negative effects of stress and promotes the ability to adapt. ${ }^{2}$ Others see it as a process in which the family reorganizes itself after a period of crisis, with the family unit being all-important, since a systemic focus and functional unity strengthen the individual and the unit to which they belong. ${ }^{3-7}$ Others believe that resilience is a personal ability or characteristic. ${ }^{8-10} \mathrm{~A}$ number of studies have suggested that environmental conditions favor the development of resilience. ${ }^{11}$ Therefore, this could be a strategy or an ability that enables humans to impose themselves when faced with adversities in their lives, allowing them to overcome the problem and adapt, thereby recovering, or even transforming their lives., ${ }^{72-14}$

Human beings are able to adapt to a wide range of situations. However, taking care of a family member who has a chronic illness, especially a degenerative illness such as Alzheimer's disease, can affect the resistance levels of an individual. According to the American Psychiatric Association, ${ }^{15}$ dementia represents evidence of significant cognitive decline, which impairs the memory and at least one other cognitive function (attention, executive functions, learning). This can lead to the loss of intellectual capacity, which affects the social and professional functioning of an individual.

According to Alzheimer's Disease International, ${ }^{16}$ the most common form of dementia is Alzheimer's disease (AD), which corresponds to between $50 \%$ and $60 \%$ of all cases and represents one of the main causes of incapacity in adult life, followed by vascular dementia (VD), which represents between 15\% and 20\%.

The overburdening of caregivers who work with individuals suffering from dementia occurs as a result of a series of physical, psychological, emotional, social and financial problems, as such caregivers generally take responsibility for the care network required by the patient. However, caregivers are often not aware of how to adequately deal with the elderly, which can lead to a state of chronic stress, with occasional social isolation, thereby further increasing the risks of the caregiver suffering from physical and mental pathologies (depression, anxiety and burnout). ${ }^{17}$

While resilience is the response to the totality of the context under experimentation, coping is the response to a moment and provides a solution to a certain situation. The sum of these two coping scenarios does not always guarantee the resistance of the individual. A fundamental characteristic of coping strategies is the fact that they are conscious and intentional, in that the stressor is perceived and analyzed consciously. Constant cognitive and behavioral alterations are required in order to manage specific, internal and/ or external demands, ${ }^{17}$ which leads to coping being seen as a tactic, rather than a personality trait of the individual, with a focus on the person's actions at a certain moment in time. 
The aim of this systematic review was to identify possible factors that are associated with the development of resilience in family caregivers who care for individuals with dementia, as well as the effect of this resilience on outcomes for the caregiver and the patient.

\section{METHOD}

This systematic literature review was conducted in accordance with the Preferred Reporting Items for Systematic Reviews and Meta-Analysis (PRISMA) methodology proposed by Moher et al..$^{18}$ This method was created to help researchers and authors to improve the communication, results and methodological rigor of their systematic reviews and meta-analysis. It can also be used for critical assessments of previously published systematic reviews.

\section{Search strategy}

This review was conducted in January and February of 2014 in the following databases: LILACS; PsycINFO; PubMed.; Scielo; SCOPUS and Web of Science.

The search descriptors were obtained from the MeSH and DeCS. The following operations were carried out in the databases: "psychological resilience AND dementia"; "psychological resilience AND family AND dementia"; "psychological resilience AND Alžbeimer's disease"; "psychological resilience AND caregivers" and "psychological resilience AND Alsheimer's disease AND caregivers".
Identification and screening

The following Inclusion criteria were used to screen the articles: publications in English, Spanish or Portuguese; in peer-reviewed journals; without publication date limits; with a full version of the text available. Review articles were excluded.

The article selection was performed independently and the two investigators (CSSM and AGB) were blinded. They first assessed the titles and abstracts compiled in the databases. After the articles had been selected, a meeting was held to form a consensus and dispel doubts and disagreements between the data collected by the investigators, as per the PRISMA protocol.

\section{Eligibility selection criteria}

The following study types were considered eligible: (1) cross-sectional and longitudinal studies of family caregivers who look after people with a diagnosis of some form of dementia; (2) studies that associated resilience with other variables or theories related to caregivers, such as coping and overburden; (3) studies of adults (+18); and (4) studies that sought to understand the resilience of caregivers both objectively and subjectively.

\section{RESULTS}

Figure 1 displays the synthesis of the methods used and the findings. In total, 384 articles were identified. Of these, only 13 studies were selected for this review. 


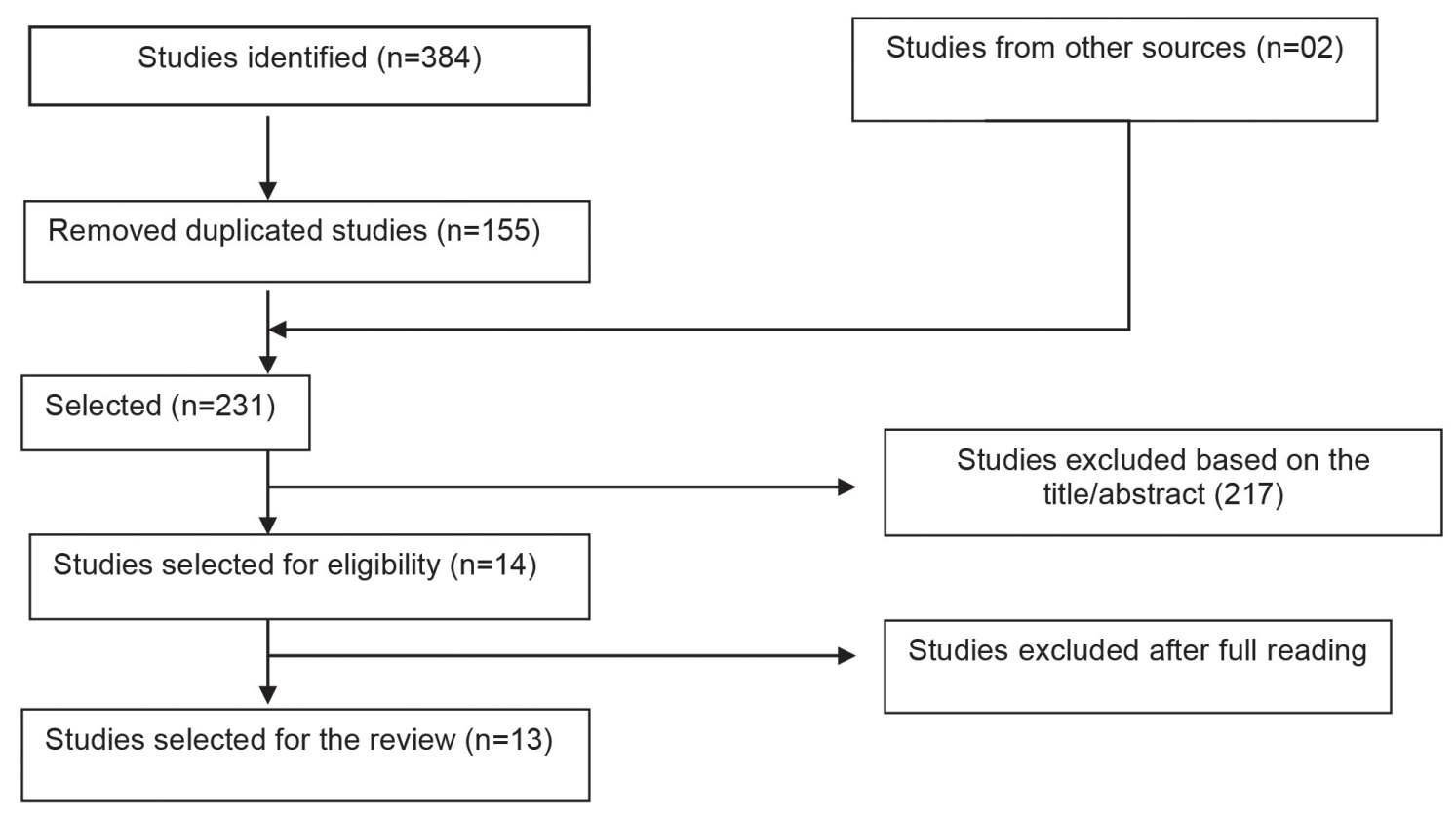

Figure 1. Selection and identification process of the articles. São Carlos, São Paulo, 2015.

Of the studies used in this review, six $(46 \%)$ were published between 2001 and 2009, three (23\%) were published between 2010 and 2011 and four (31\%) were published between 2012 and 2013. Most of the studies (46\%) were published in the USA, while $31 \%$ were published in Brazil, with $8 \%$ published in each of Canada, Spain and Portugal. (TOTAL OF 101\%).
Concerning the methodology used in these studies, 12 applied a quantitative approach and one used a qualitative approach, while seven (54\%) were longitudinal and six $(46 \%)$ were cross-sectional. Two studies $(15 \%)$ were experimental. Table 1 displays the synthesis of the studies selected.

Table 1. Synthesis of studies selected for the review. São Carlos, São Paulo, 2015.

\begin{tabular}{|c|c|c|c|c|c|}
\hline Author/Year & Location & Design & $\mathrm{n}$ & Age & Main findings \\
\hline $\begin{array}{l}\text { Loureiro } \\
(2009)\end{array}$ & Porto, Portugal & $\begin{array}{l}\text { Quantitative/ } \\
\text { cross-sectional }\end{array}$ & 32 & $61 *$ & $\begin{array}{l}\text { Coping associated with overburden. Spouses } \\
\text { exhibit less negative symptoms. }\end{array}$ \\
\hline $\begin{array}{l}\text { Lopes, } \\
\text { Massinelli } \\
(2013)\end{array}$ & Sao Paulo, Brazil & $\begin{array}{l}\text { Qualitative/ } \\
\text { cross-sectional }\end{array}$ & 10 & $57^{*}$ & $\begin{array}{l}\text { Social and family resources contribute to an } \\
\text { increase in resilience. }\end{array}$ \\
\hline $\begin{array}{l}\text { Lampert } \\
(2009)\end{array}$ & $\begin{array}{l}\text { Porto Alegre, } \\
\text { Brazil }\end{array}$ & $\begin{array}{l}\text { Quantitative/ } \\
\text { longitudinal }\end{array}$ & 20 & $55-78$ & $\begin{array}{l}\text { Lower levels of resilience associated with } \\
\text { symptoms of depression and stress. }\end{array}$ \\
\hline $\begin{array}{l}\text { Scott } \\
(2010)\end{array}$ & Knoxville, USA & $\begin{array}{l}\text { Quantitative/ } \\
\text { cross-sectional }\end{array}$ & 111 & $63^{*}$ & $\begin{array}{l}\text { Lower levels of resilience associated with } \\
\text { overburden. }\end{array}$ \\
\hline $\begin{array}{l}\text { Garces et al } \\
(2012)\end{array}$ & Cruz Alta, Brazil & $\begin{array}{l}\text { Quantitative/ } \\
\text { cross-sectional }\end{array}$ & 06 & $40-69$ & Resilience associated with older caregivers. \\
\hline
\end{tabular}




\begin{tabular}{|c|c|c|c|c|c|}
\hline $\begin{array}{l}\text { Clay et al } \\
(2008)\end{array}$ & $\begin{array}{l}\text { Birmingham, } \\
\text { USA }\end{array}$ & $\begin{array}{l}\text { Quantitative/ } \\
\text { longitudinal }\end{array}$ & 166 & $60 *$ & $\begin{array}{c}\text { Resilience in terms of satisfaction with life/ } \\
\text { social support and less depressive symptoms } \\
\text { among black people. }\end{array}$ \\
\hline $\begin{array}{l}\text { Lavrestsky, } \\
\text { Siddarth, } \\
\text { Irwin }(2010)\end{array}$ & $\begin{array}{l}\text { Los Angeles, } \\
\text { USA }\end{array}$ & $\begin{array}{l}\text { Quantitative/ } \\
\text { longitudinal }\end{array}$ & 40 & 43-91 & $\begin{array}{c}\text { A } 10 \mathrm{mg} / \text { day dose of escitalopram improves } \\
\text { resilience. }\end{array}$ \\
\hline $\begin{array}{l}\text { Roth et al } \\
(2001)\end{array}$ & $\begin{array}{l}\text { Birmingham, } \\
\text { USA }\end{array}$ & $\begin{array}{l}\text { Quantitative/ } \\
\text { longitudinal }\end{array}$ & 197 & $59,7^{*}$ & $\begin{array}{l}\text { The effects of resilience on symptoms of } \\
\text { depression and life satisfaction were higher } \\
\text { among black people. }\end{array}$ \\
\hline $\begin{array}{l}\text { Haley et al } \\
(2008)\end{array}$ & Tampa, USA & $\begin{array}{l}\text { Quantitative/ } \\
\text { longitudinal }\end{array}$ & 254 & $71,1 *$ & Psychological support improves resilience. \\
\hline $\begin{array}{l}\text { Gaioli, } \\
\text { Furegato, } \\
\text { Santos } \\
(2012)\end{array}$ & $\begin{array}{l}\text { Ribeirao Preto, } \\
\text { Brazil }\end{array}$ & $\begin{array}{l}\text { Quantitative/ } \\
\text { cross-sectional }\end{array}$ & 101 & $+18^{* *}$ & $\begin{array}{l}\text { Better socioeconomic conditions, lifestyle } \\
\text { habits, health conditions and child/parent } \\
\text { relationships favor resilience. }\end{array}$ \\
\hline $\begin{array}{l}\text { Gaugler, } \\
\text { Kane, } \\
\text { Newcomer } \\
(2007)\end{array}$ & $\begin{array}{c}\text { Rochester, } \\
\text { Urbana, } \\
\text { Memphis, } \\
\text { Portland, } \\
\text { Cincinnati, } \\
\text { Parkersburgs, } \\
\text { Minneapolis and } \\
\text { Miami, USA }\end{array}$ & $\begin{array}{l}\text { Quantitative/ } \\
\text { longitudinal }\end{array}$ & 1979 & $63,32 *$ & $\begin{array}{l}\text { High resilience associated with less overburden, } \\
\text { a lower frequency of institutionalization and } \\
\text { death among people in care. }\end{array}$ \\
\hline $\begin{array}{l}\text { Fernández- } \\
\text { Lansac et al } \\
\text { (2012). }\end{array}$ & $\begin{array}{l}\text { Madrid, } \\
\text { Salamanca and } \\
\text { Zamora, Spanish }\end{array}$ & $\begin{array}{l}\text { Quantitative/ } \\
\text { cross-sectional }\end{array}$ & 53 & $63,18^{*}$ & $\begin{array}{l}\text { Resilience associated with the best physical/ } \\
\text { emotional state, better healthy habits, less } \\
\text { overburden and neuroticism, and greater } \\
\text { extroversion, self-efficacy, self-esteem and } \\
\text { coping skills. }\end{array}$ \\
\hline $\begin{array}{l}\text { O’Rourke et al } \\
(2010)\end{array}$ & $\begin{array}{l}\text { Vancouver, } \\
\text { Canada }\end{array}$ & $\begin{array}{l}\text { Quantitative/ } \\
\text { longitudinal }\end{array}$ & 105 & $69,59 *$ & $\begin{array}{l}\text { Resilience as a perceived control and the } \\
\text { challenge-stability ratio as a predictor of } \\
\text { depressive symptoms. }\end{array}$ \\
\hline
\end{tabular}

$*_{\text {mean age }}^{* *}$ non-specified limit.

In the studies included in this review, resilience was most commonly associated with depression symptoms in the caregiver (38\%), followed by the overburden of the caregiver (31\%) and drug use $(23 \%)$. Degree of kinship with the elderly individual, black ethnicity/skin color, health conditions, lifestyle habits and life satisfaction seem to affect the resilience of caregivers, appearing in $15 \%$ of the studies. Anxiety, self-efficacy, selfesteem, tiredness, discouragement, coping skills, burnout, emotional condition, physical condition, stress, extroversion, age, neuroticism, social/ family resources, satisfaction with social support, socioeconomic conditions, psychological support and medical treatment were all mentioned with similar frequency $(8 \%)$.

\section{DISCUSSION}

Two complementary longitudinal studies found psychological differences between different 
ethnic groups of caregivers. Roth et al. ${ }^{19}$ spent two years monitoring 197 family caregivers of people with dementia and 218 non-caregivers, assessing depression, physical health and satisfaction. The authors sought to identify differences between white and black caregivers. The results suggested that white caregivers exhibited higher levels of depression over time, when compared with black caregivers. African-American caregivers exhibited a higher level of life satisfaction and were found to be more resilient against symptoms of depression, although they were vulnerable to increases in physical symptoms over time. Both groups of caregivers reported an increase in physical symptoms over time. However, resilience was both a positive association and a moderating factor, attenuating the symptoms of depression among black caregivers. ${ }^{19}$ Similar results were reported by Clay et al. ${ }^{20}$ who spent five years monitoring a sample of 166 American caregivers (mean age of 60 years) who cared for individuals that had been classified with dementia. The aim of the study was to analyze their satisfaction with social support and depression symptoms, thereby confirming the resilience found among white and black caregivers. Concerning age, black caregivers were younger than white caregivers, with women more commonly performing this role. As in the above mentioned study, black caregivers exhibited higher levels of life satisfaction than white caregivers, as well as fewer symptoms of depression. The resilience of black caregivers was positively associated with their high levels of satisfaction with social support and life in general, as well as their low levels of depressive symptoms, when compared with white caregivers. The results suggest that low levels of social support have an effect on resilience and are a possible precursor for psychological poverty. Dias et al. ${ }^{21}$ studied concepts, methodological approaches and determining models related to the resilience of caregivers who work with individuals suffering from dementia. The authors found that high levels of resilience were correlated with low levels of depression and better physical health and concluded that social support was a moderating factor, since depending on a variety of types of support seems to relieve the physical and mental overburden caused by stress.
A number of experimental studies have used interventions to assess the factors that influence the resilience of caregivers. Haley $e t$ al. ${ }^{22}$ spent two years monitoring a randomized sample of 254 caregivers (mean age of 71.1 years) of deceased individuals who had suffered from dementia. The aim of the study was to analyze the joint effects of mourning and care intervention on the depressive symptoms of caregivers. Psychological support was offered to a group of caregivers in the form of an intervention. The caregivers who received the intervention were significantly more resilient and less likely to develop depressive symptoms before and after mourning, which suggests resilience to depression. Conversely, the control caregivers were more likely to exhibit chronic depressive symptoms before and after mourning. The authors suggested that caregivers who possess knowledge, abilities and support (interventions) may find valuable resources in the detachment of assistance, as well as facing challenges such as dealing with the death of a loved one. ${ }^{22}$ It is possible to infer that resilience and the support received (social, family or psychological, when required) serve as a protection factor, enabling caregivers to face the adversities of life more effectively. Lavrestsky et al. conducted a 12-month experimental study with 40 caregivers (aged 43 to 91 years) of people with AD. Of these 40 participants, 25 were children of patients, while 15 were spouses of patients. In total, $65 \%$ of the sample were women. The participants received $10 \mathrm{mg} /$ day of escitalopram or a placebo (two groups) and the following outcomes were analyzed: the intensity of depression; overburden; resilience; anguish; quality of life; level of cognitive abnormality in the individual with dementia and their behavioral disorders at the beginning of (and throughout) the treatment. The use of escitalopram triggered the remission of severe symptoms of depression, while also improving anxiety, resilience, overburden and quality of life. The use of anti-depressants improved the resistance of the caregiver. ${ }^{23}$ A Brazilian study conducted by Manzini ${ }^{24}$ sought to assess the factors associated with the resilience of family caregivers of elderly individuals with Alzheimer's. The authors conducted multiple linear regression analysis and found that several factors negatively 
affected the level of resilience. These included the mean self-perception of mental health among the caregivers, being from the middle and upper economic classes and symptoms that suggested depression. ${ }^{24}$ Alzheimer's disease leads to a great demand for attention from the caregiver, which inevitably damages their own health, leading to depression and other disorders. Clinical support is often required to find a cure for these disorders or to maintain the physical and/or mental health of the caregiver. Gaioli et al. ${ }^{25}$ reported that resilience is correlated with several variables. In a sample containing 101 Brazilian citizens aged between 18 and 45 years, all of whom cared for elderly individuals with Alzheimer's, the authors sought to describe the socio-demographic and health variables of the caregivers and to analyze associations with resilience. Of the caregivers in this sample, $83.1 \%$ were female, $57.4 \%$ had studied for up to eight years, and $80.1 \%$ were older than 46 years of age, with $36.6 \%$ of these older than 60 years. Socio-demographic conditions, lifestyle habits and health conditions affected the resilience of the caregiver. Despite the difficulties involved in caring for an elderly person with Alzheimer's, the caregivers were able to perform their duties more effectively when they had some knowledge of the disease and received help from others. Significant associations were found between resilience and the following variables: the degree of kinship (caregivers who were children of the patient were considered more resilient than spouses, siblings, sisters-in-law and others); medical treatment (43.1\% of the caregivers who were receiving some form of medical treatment exhibited poor resilience); drug use $(60.0 \%$ of the caregivers who used drugs exhibited a medium to high level of resilience); tiredness $(76.0 \%$ of the caregivers who exhibited tiredness had a low to moderate level of resilience); exhaustion and discouragement $47.8 \%$ of the caregivers that did not exhibit exhaustion and discouragement had a high level of resilience). Physical health was significantly associated with the experience of the caregiver, since $81.1 \%$ of the elderly in care suffered from severe cognitive issues. The authors suggested that in a family context, elderly individuals may benefit from the presence of a more resilient caregier. ${ }^{25}$
In Spain, Fernández-Lansac et al. ${ }^{26}$ assessed a sample of 53 caregivers who worked with patients with dementia. In total, $66 \%$ of these caregivers were female, while the mean age was 63.1 years. Concerning the degree of kinship, $54.7 \%$ were spouses and $37.7 \%$ were children of the elderly patients. The aim of this study was to assess resilience and establish variables associated with stress factors (the level of cognitive impairment of the elderly individual), the overburden of the caregiver, personality characteristics, resources and the consequences of the care on the physical and emotional health of the caregiver. The caregivers achieved moderate scores for resilience, which was significantly associated with worse physical and emotional conditions in the caregiver, while higher scores were associated with less anxiety, less depression, lower drug consumption and the absence of psychological interventions. Higher resilience scores were also significantly correlated with levels of overburden, low levels of neuroticism, high levels of extroversion, self-efficacy, self-esteem and self-care, less use of coping strategies that focused on emotions and less changes in healthy habits. The authors concluded that resilience is associated with better physical and emotional conditions and the capacity to deal with adverse situations. ${ }^{26}$

In Canada, O'Rourke et al. ${ }^{27}$ used a longitudinal study to analyze resilience (assessed through perceived control, life commitment and the challenge versus stability ratio) as a predictor of depressive symptoms among married caregivers over the course of a year (mean age of 69 years). In total, 58 of the caregivers were wives of individuals with (probable) Alzheimer's, while 47 of the caregivers were husbands of patients. The study also sought to correlate these resilience factors with socio-demographic variables and variables related to dementia. The analysis confirmed that resilience, direction and the magnitude of the change in resilience over time were distinct predictors of depressive symptoms. Perceived control and challenges predicted lower levels of depressive symptoms over the course of a year, while an increase in the challenge predicted less depressive symptoms. Conversely, life commitment 
was not a significant predictor of depression among caregivers. ${ }^{27} \mathrm{~A}$ study that sought to describe the correlations between functionality, depressive symptomatology and cognition among groups of resilient and non-resilient elderly individuals found that resilience was negatively correlated with depressive symptomatology, thereby demonstrating that elderly individuals with high resilience exhibit less depressive symptomatology. ${ }^{28}$ Depression, stress, overburden and psychological characteristics, as well as social, economic and family resources, have been significantly associated with resilience. A Brazilian study by Lampert ${ }^{29}$ sought to investigate how social support networks and resilience affect the psychological, neuroendocrine and immunological abnormalities involved in the chronic stress of caregivers who work with dementia patients. The age of the caregivers $(\mathrm{n}=20)$ ranged from 55 to 78 years. Resilience was inversely associated with depression and stress, but was not correlated with neuroendocrine and immunological responses. Chronic stress was correlated with an emotional overburden among caregivers. In this study, low levels of cortisol may have been associated with the psychological exhaustion of the caregivers, although emotional overburden did not increase the level of cortisol. Resilience and social support attenuated certain effects of chronic stress related to the emotional overburden of caregivers. ${ }^{29} \mathrm{~A}$ descriptive study of family caregivers of elderly individuals with chronic illnesses reported moderate scores for overburden among the sample. The authors concluded that caregivers who believed that the care they provided was a great responsibility exhibited the greatest overburden. ${ }^{30}$ Gratão et al..$^{31}$ sought to describe the overburden and emotional discomfort of caregivers working with elderly patients and found that older caregivers are more susceptible to overburden, although younger caregivers may suffer from isolation and greater social restrictions. Other issues related to overburden included taking on tasks beyond the scope of those performed in the home, resulting in an accumulation of roles and an overburden in their social, physical, emotional and spiritual lives.
Garces $e t a l .32$ interviewed six caregivers aged between 40 and 69 years in order to assess the resistance of caregivers who work with elderly individuals suffering from Alzheimer's disease and correlate it with other psychological variables. Of the six caregivers, five were female, three were married, four were the child of the patient and two were the spouse of the patient. The results suggested that, although most of the caregivers exhibited the probability of developing psychiatric disorders, they also exhibited a high disposition to resilience, thereby confirming that they were capable of facing the adversities involved in dealing with Alzheimer's disease. It was also notable that there was a significant association between resilience and age, in that the oldest caregivers exhibited the greatest levels of resilience. ${ }^{32}$

In Portugal, Loureiro ${ }^{33}$ set out to assess physical, emotional and social overburden and correlate these with other variables among 32 informal caregivers who worked with elderly individuals suffering from dementia. The characteristics of the sample were: $71.9 \%$ were female; $46.9 \%$ were elderly; $87.5 \%$ were married; $37.5 \%$ had completed a primary education; $43.8 \%$ were the spouse of the elderly patient; $37.5 \%$ were a child of the elderly patient; $12.5 \%$ were the son/daughter-in law of the elderly patient; $6.2 \%$ were other relatives; $21 \%$ had been caring for the patient for more than five years and $71.8 \%$ of the elderly patients were female. The results demonstrated that emotional overburden was the most affected dimension among caregivers of both genders. However, women have a greater perception of overburden, given that they spend more time caring for others, their health is affected to a greater extent and they cite greater social restrictions than men. Psychological coping mechanisms were found to be predictors of overburden. No correlations were found between overburden and the stage of dementia or the length of time caring for the patient. Spouses of the elderly patients reported less negative sentiments about caring for the patient than children and other relatives. Therefore, the results confirmed that informal caregivers exhibited considerable levels of physical, emotional and social overburden. ${ }^{33}$ 
According to Manzini, the task of caring for a family member with Alzheimer's demands almost exclusive dedication on behalf of caregivers, who often do not have time to look after themselves. They do not perform any physical activities or exercise and end up leaving aside their affairs at the expense of the care they provide. Caregivers may feel overburdened and exhausted as a result of the intensity of the care required by elderly individuals with AD. ${ }^{24}$ Similar results were reported by $\mathrm{Scott}^{34}$ in a study conducted in North America. The authors interviewed 111 caregivers of individuals with AD to determine the moderating effect of resilience on the correlation between stress and predictors of overburden. The results showed that resilience is not a moderating factor between stress and overburden. However, there was an inverse correlation between the scores for resilience and overburden: greater resilience levels led to lower levels of overburden for the caregiver. The authors concluded that these findings show the importance of caregivers of individuals with Alzheimer's and the implementation of support/interventions that increase their resilience. ${ }^{34}$ Reppold et al. ${ }^{35}$ highlighted the fact that being resilient in a given situation does not guarantee or predict that the individual will be resilient the next time something similar happens, nor does it confirm that they will be resilient in other situations. The authors also stressed that changes to a social support network could have more of an impact on the capacity to successfully face risky situations than individual variables, such as anxiety, depression and stress, among others.

Concerning the high resilience found among caregivers, two previous studies provided similar results. Gaugler et al. ${ }^{36}$ analyzed the data of 1979 caregivers, of whom the majority $(77.8 \%)$ were female (mean age of 63.3 years) spouses who cared for their elderly partner (with dementia) for more than four years. Logistical regression analysis confirmed that high resilience (less overburden in the context of high care demands) in the initial measurement was associated with a lower prevalence of institutionalization, the loss of monitoring and a lower rate of mortality for the people in care. ${ }^{36}$ It can be inferred, hypothetically, that greater levels of resilience in the caregiver are correlated to better adaptation skills when faced with these adversities, an improved capacity to face problems, and an improvement in their performance in the eyes of the patient, all of which benefit both the patient and the caregiver. Lopes \& Massinelli ${ }^{37}$ used a qualitative methodology to determine the profile of 10 informal caregivers of elderly individuals with AD and their level of resilience. Nine of the caregivers (mean age of 57 years) were female, while seven had completed both high school and a third level course. Six received help when caring for the patient and all of the caregivers exhibited high levels of resilience. The findings also confirmed the negligence of the caregivers in relation to taking care of themselves. All of the caregivers claimed not to be interested in institutionalizing the elderly individual with dementia. The presence of professional support, such as convenience centers, helped to increase the resilience and coping skills of the caregiver, when faced with adverse situations. The fact that the caregiver was married also increased resilience, since sharing their care-related tasks and other responsibilities with their partner decreased the occurrence of overburden. Positive psychological adaptation when faced with these unfavorable situations, allied to financial, social and family support, lightens the emotional and physical burden on the caregiver, making them more capable of facing challenges, less vulnerable to health problems and more prepared to offer the best quality assistance to the elderly individual. ${ }^{37}$

Understanding the resilience of caregivers of elderly individuals with dementia and its associated factors favors the implementation of health services and the search for solutions that can contribute to improvements in emotional disorders such as anxiety, stress and depression.

Based on the data extracted from this review, a fluxogram was created to explain the factors associated with resilience and its respective outcomes. 


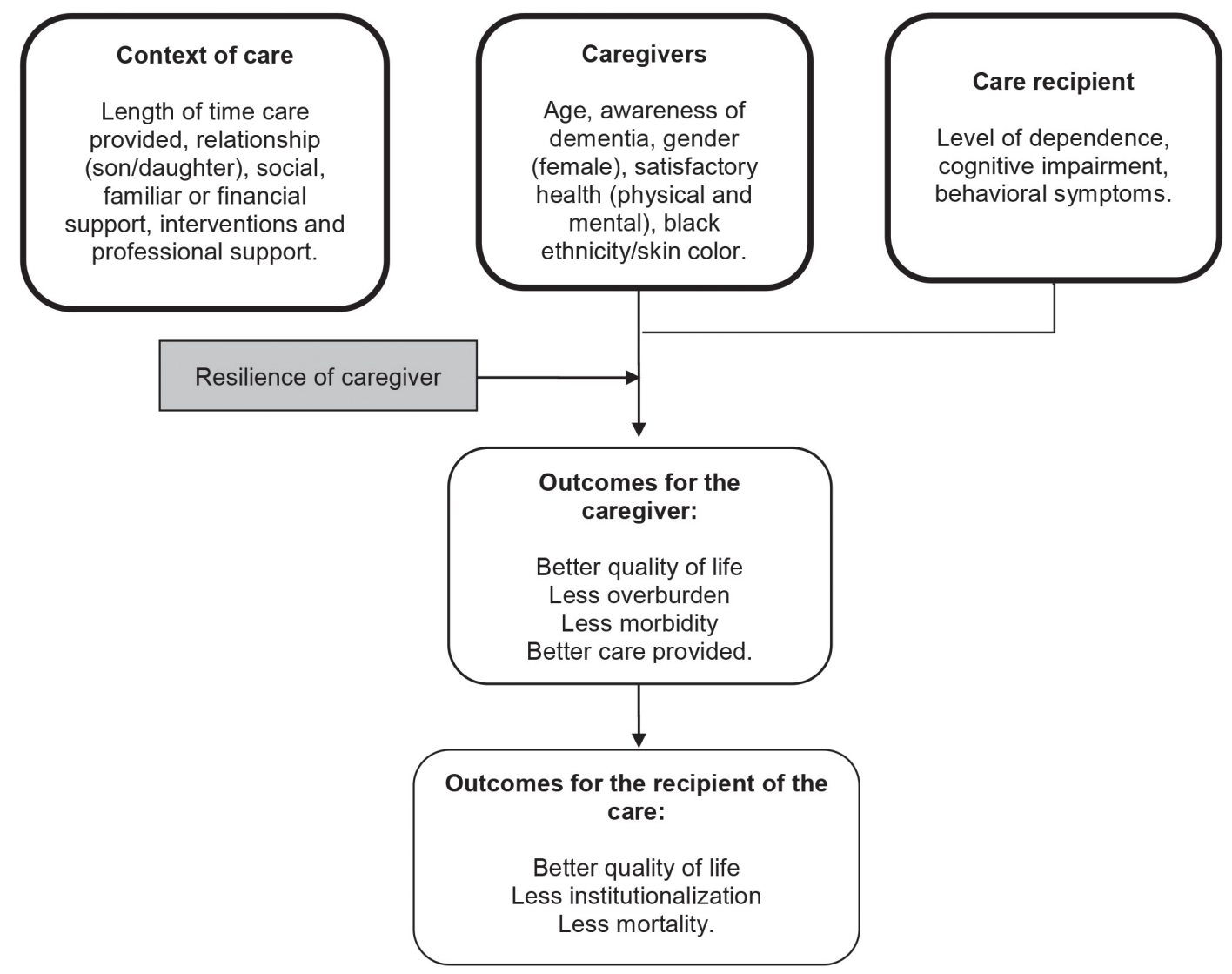

Figure 2. Fluxogram of the main factors associated with the development of resilience in the caregiver and its outcomes. São Carlos, São Paulo, 2015.

\section{CONCLUSION}

Based on the studies analyzed, depression, anxiety, stress, overburden and drug use are extremely common in the daily lives of family caregivers of people with dementia.

A number of variables seem to affect the increase in the resilience of caregivers, including: the degree of kinship to the patient; black ethnicity/skin color; a satisfactory quality of life; healthy lifestyle habits; optimism and life satisfaction. Resilience was also promoted by family, social and financial support, as well as assistance with or division of responsibilities, better physical and emotional conditions (of the caregiver) and awareness of the illness. These factors ease the physical and emotional overburden of the caregiver, while strengthening the possibility of dealing with adversity and challenges, which is consequently reflected in the quality of the assistance received by the patient.

As proposed, the present study identified factors associated with the development of resilience in caregivers with previously established characteristics, while also creating a fluxogram containing the main factors associated with the development of resilience and the attenuating effects (direct and indirect) of this development on the outcomes of caregivers and patients. 


\section{ACKNOWLEDGEMENTS}

The authors would like to thank Prof. Dr. Aline Cristina Martins Gratão for her useful contribution to the theoretical concepts, as well as the Coordenação de Aperfeiçoamento de Pessoal de Nível Superior (Coordination for the Improvement of Higher
Education Personnel) (CAPES), the Fundação de Amparo à Pesquisa do Estado de São Paulo (Sao Paulo Amparo Research Foundation) (FAPESP) and the Conselho Nacional de Desenvolvimento Cientifico e Tecnológico (National Council for Scientific Development and Technology) (CNPq) for their financial support in the form of study grants.

\section{REFERENCES}

1. Peltz L, Moraes MG, Carlotto MS. Resiliência em estudantes do ensino médio. Psicol Esc Educ [Internet] 2010 [acesso em 12 mai 2013];14(1):87-94. Disponível em: http://www.scielo.br/pdf/pee/v14n1/v14n1a10.pdf

2. Ahern NR, Kiehl EM, Sole ML, Byers J. A review of instruments measuring resilience. Issues Compr Pediatr Nurs 2006;29(2):103-25.

3. Walsh F. Family resilience: a framework for clinical practice. Fam Process [Internet] 2003 [acesso em 12 mai 2013];42(1):1-18. Disponível em: http://www.celf. ucla.edu/2010_conference_articles/Walsh_2003.pdf

4. Walsh F. The concept of family resilience: crisis and challenge. Fam Process [Internet] 1996 [acesso em 12 mai 2013];35(3):261-81. Disponível em: http://onlinelibrary.wiley.com/doi/10.1111/j.15455300.1996.00261.x/pdf

5. Walsh F. Traumatic loss and mayor disasters: strengthening family and community resilience. Fam Process [Internet] 2007 [acesso em 12 mai 2013];46(2):207-27. Disponível em: http://www. familyprocess.org/data/featured_articles/71_ walsh2007.pdf

6. Yunes MAA, Szymanski H. Entrevista Reflexiva e Grounded Theory: estratégias metodológicas para compreensão da resiliência em famílias. Rev Interam Psicol [Internet] 2005 [acesso em 12 mai 2013];39(3):431-38. Disponível em: http://www.psicorip. org/Resumos/PerP/RIP/RIP036a0/RIP03950.pdf

7. Yunes MAM, Szymanski H. O estudo de uma família "que supera as adversidades da pobreza": caso de resiliência familiar? Rev Psicodebate, Psicol, Cult Soc [Internet] 2008 [acesso em 12 mai 2013];(7):119-40. Disponível em: http://www. palermo.edu/cienciassociales/publicaciones/pdf/ Psico7/7Psico\%2008.pdf

8. Pinheiro DPN. A resiliência em discussão. Psicol Est [Internet] 2004 [acesso em 12 mai 2013];9(1):67-75. Disponível em: http://dx.doi.org/10.1590/S141373722004000100009
9. Greco C, Morelato G, Ison M. Emociones positivas: una herramienta psicológica para promocionar el proceso de resiliência infantil. Rev Psicodebate, Psicol, Cult Soc [Internet] 2006 [acesso em 12 mi 2013];7:81-94. Disponível em: http://www. palermo.edu/cienciassociales/publicaciones/pdf/ Psico7/7Psico\%2006.pdf

10. Oliveira MA, Reis VLZ, Zanelato LSN, Bueno CM. Resiliência: análisis de las publicaciones em el período de 2000 a 2006. Psicol Ciênc Prof [Internet] 2008 [acesso em 12 mai 2013];28(4):75467. Disponível em: http://pepsic.bvsalud.org/ scielo.php?script $=$ sci_arttext\&pid $=\mathrm{S} 1414$ 98932008000400008\&lng=pt\&nrm=iso

11. Sequeira VC. Resiliência e abrigos. Bol Acad Paul Psicol [Internet] 2009 [acesso em 12 mai 2013];29(1):65-80. Disponível em: http://pepsic. bvsalud.org/scielo.php?script=sci_arttext\&pid=\$1415 711X2009000100007\&lng=pt\&nrm=iso

12. Chiesa AM. Autonomia e resiliência: categorias para o fortalecimento da intervenção na atenção básica na perspectiva da Promoção da Saúde [tese]. São Paulo: Universidade de São Paulo; 2005 [acesso em 12 mai 2013]. Disponível em: http://www.teses. usp.br/teses/disponiveis/livredocencia/7/tde24082009-153734

13. Noronha MGRCS, Cardoso PS, Moraes TNP, Centa ML. Resiliência: nova perspectiva na promoção da saúde da família. Ciênc Saúde Coletiva [Internet] 2009 [acesso em 12 mai 2013];14(2):497-506. Disponível em: http://dx.doi.org/10.1590/S141381232009000200018

14. Truzzi A, Souza W, Bucasio E, Berger W, Figueira I, Engelhardt E, et al. A multinational review of recent trends and reports in dementia caregiver burden. Eur J Psychiatry 2008;22(3):151-60.

15. American Psychiatric Association. Manual diagnóstico e estatístico de transtornos mentais: DSM-V-TR. $5^{a}$ ed. Belo Horizonte: Artmed; 2014. p. 611-16. 
16. Alzheimer's Disease International. World Alzheimer Report 2009 [Internet]. London: Alzheimer's Disease International; [2012?] [acesso em 12 mai 2013]. Disponível em: http://www.ge.co.uk/research/files/ WorldAlzheimerReport.pdf.

17. Lazarus RS, Folkman S. Stress, appraisal and coping. New York: Springer; 1984.

18. Moher D, Liberati A, Tetzlaff J, Altman DG; The PRISMA Group. Preferred reporting items for systematic reviews and meta-analyses: the PRISMA Statement. PLoSMed [Internet] 2008 [acesso em 12 mai 2013]. Disponível em: 10.1371/journal. pmed.1000097

19. Roth DL, Haley WE, Owen JE, Clay OJ, Goode KT. Latent Growth Models of the Longitudinal Effects of Dementia Caregiving: a comparison of African American and White Family Caregivers. Psychol Aging 2001;16(3):427-36.

20. Clay OJ, Roth DL, Wadley VG, Haley WE. Changes in social support and their impact on psychosocial outcome over a 5-year period for African American and White dementia caregivers. Int J Geriatr Psychiatry [Internet] 2008 [acesso em 12 mai 2013];23:857-62. Disponível em: 10.1002/gps.1996

21. Dias R, Santos RL, Sousa MF, Nogueira MM, Torres $\mathrm{B}$, Belfort T, et al. Resilience of caregivers of people with dementia: a systematic review of biological and psychosocial determinants. Trends Psychiatry Psychother 2015;20(10);1-8.

22. Haley WE, Bergman EJ,Roth DL, McVie T, Gaugler JE, Mittelman MS. Long-Term Effects of Bereavement and Caregiver Intervention on Dementia Caregiver Depressive Symptoms. Gerontologist 2008;48(6):732-40.

23. Lavretsky H, Siddarth P, Irwin MR. Improving depression and enhancing resilience in family dementia caregivers: a pilot randomized placebo-controlled trial of escitalopram. Am J Geriatr Psychiatry [Internet] 2010 [acesso em 12 mai 2013];18(2):154-64. Disponível em: 10.1097/JGP.0b013e3181beable

24. Manzini CSS. Resiliência em cuidadores familiares de idosos com doença de Alzheimer [dissertação]. São Carlos: Universidade Federal de São Carlos; 2015.

25. Gaioli CCLO, Furegato ARF, Santos JLF. Perfil de Cuidadores de Idosos com Doença de Alzheimer Associado à Resiliência. Texto \& Contexto Enferm 2012;21(1):150-7.
26. Fernández-Lansac V, López MC, Cáceres R, Rodríguez-Poyo M. Resiliencia en cuidadores de personas com demencia: estudio preliminar. Rev Esp Geriatr Gerontol 2012;47(3):102-9.

27. O'Rourke R, Kupferschmidt AL, Claxton A, Smith JZ, Chappell N, Beattie BL. Psychological resilience predicts depressive symptoms among spouses of persons with Alzheimer disease over time. Aging Ment Health 2010;14(8):984-93.

28. Fontes AP, Fattori A, D’Elboux MJ, Guariento ME. Resiliência psicológica: fator de proteção para idosos no contexto ambulatorial. Rev Bras Geriatr Gerontol 2015;18(1):7-17.

29. Lampert SS. Rede de apoio social, resiliência e marcadores imunológicos em idosos cuidadores de pacientes com demência [dissertação]. Porto Alegre: PUCRS; 2009.

30. Manoel MF. As relações familiares e o nível de sobrecarga do cuidador familiar. Esc Anna Nery Rev Enferm 2013;17(2):346-53.

31. Gratão ACM. Sobrecarga e desconforto emocional em cuidadores de idosos. Texto \& Contexto Enferm 2012;21(2):304-12.

32. Garces SB, Krug MR, Hansen D, Brunelli AV, Costa FTL, Rosa CB, et al. Avaliação da resiliência do cuidador de idosos com Alzheimer. Rev Bras Geriatr Gerontol 2012;15(2):335-52.

33. Loureiro NV. A sobrecarga física, emocional e social dos cuidadores informais de idosos com demência [dissertação]. Porto: Universidade Fernando Pessoa; 2009.

34. Scott CB. Alzheimer's Disease Caregiver Burden: does Resilience Matter? [dissertação]. Tennessee: University of Tennessee; 2010.

35. Reppold CT, Mayer JC, Almeida Leand LS, Hutz CS. Avaliação da Resiliência: Controvérsia em Torno do Uso das Escalas. Psicol Reflex Crít 2012;25(2):248-55.

36. Gaugler JE, Kane RL, Newcomer R. Resilience and Transitions From Dementia Caregiving. J Gerontol Psychol Sci 2007;62B(1):38-44.

37. Lopes SRA, Massinelli CJ. Perfil e nível de resiliência dos cuidadores informais de idosos com Alzheimer. Aletheia 2013;40:134-45. 